The Organs at Farm Street Church

Author(s): Vivian Stuart

Source: The Musical Times, Vol. 62, No. 942 (Aug. 1, 1921), p. 579

Published by: Musical Times Publications Ltd.

Stable URL: http://www.jstor.org/stable/910028

Accessed: 17-05-2016 23:11 UTC

Your use of the JSTOR archive indicates your acceptance of the Terms \& Conditions of Use, available at

http://about.jstor.org/terms

JSTOR is a not-for-profit service that helps scholars, researchers, and students discover, use, and build upon a wide range of content in a trusted digital archive. We use information technology and tools to increase productivity and facilitate new forms of scholarship. For more information about JSTOR, please contact support@jstor.org.

Musical Times Publications Ltd. is collaborating with JSTOR to digitize, preserve and extend access to The Musical Times 
to the heart and mind of humanity than do those of any other composer. It is on this ground perhaps that many musiclovers as well as professional musicians would acclaim Beethoven as the greatest of all composers, and in the June number of La Revue Musicale M. André Suares appears to support this contention. It is curious to note (at least so far as I am aware) that Beethoven is the only composer whose name has been linked with the greatest names in the sister arts of poetry and painting (Homer, Dante, Shakespeare, Michael Angelo, \&c.).

In conclusion, I beg leave to repeat a quotation from Saint-Saëns with regard to this matter: "Et parceque Beethoven a chanté la fraternité universelle, parceque son âme au lieu d'être seulement l'âme allemande est l'âme humaine, il reste le plus grand, le seul vraiment grand.'

All music-lovers, however, have their favourites. Yours, \&c.

The Avenue, Kew Gardens. K. Heatley. July I5, I92 I.

\section{ORGANISTS ON HOLIDAYS}

SIR,-The month of August will see a general egress from inland towns and a corresponding ingress at our seaside resorts. Among the visitors will be many church organists, who will doubtless visit various churches partly with a view to gaining suggestions for the improvement of their own services or to indulge criticism.

It is chiefly on behalf of seaside organists that I write, for they will doubtless be on their mettle, and strive to make the most of the material at their command.

In an article contributed to the Musical Standard four years ago, I pointed out that after a long absence from England I found the musical portion of the service had appreciably deteriorated, and further acquaintance with many churches has not caused me to alter my opinion. No organist who loves his church can contemplate with equanimity the fact that less than one-fifth of the population of Great Britain attend any place of worship to-day, and that number is rapidly diminishing. If the clergy be responsible for nine-tenths of this deplorable state of things, I do not hesitate to say that the organists are responsible for the other tenth. During this month many organists will find themselves. 'hearers, and not doers'; let them, then, try and judge the musical portion of the service from the point of view of the congregation.

I know that the idea of congregational singing is anathema to many organists, and that it will be long ere they realise that the choir exists for the congregation, and not the congregation for the choir; yet few people are content to sit Sunday by Sunday through a service in which they can take no active part. It is many years since the Church Times pointed out that the 'apeing of a Cathedral service had done more than anything to alienate the masses from attending public worship.' Personally, I am tired to death of elaborate services sung to show off the high notes of a solo boy or the quality of a bass or tenor. I want an honest, plain service, in which I can take part in the worship. If we are to be deprived of the Canticles and Psalms, surely we ought to be allowed to join in the hymns, and yet at many churches I have visited lately either the hymns are sung to totally unfamiliar tunes or played in such a way (regardless of time or rythym) that it is impossible to join in. The excuse that the organist only receives from $£ 12-£ 40$ a year does not hold good. If an organist cannot play a hymn-tune for twelve pounds per annum, he cannot do it for twelve hundred. My suggestion is to have a plain congregational service on Sundays, and a recital as elaborate as one likes once a week during the season. Copy the Nonconformist plan of printing a notice of the services and the hymns and other music on leaflets to be left at every boarding-house, with the words 'All visitors are heartily welcome.' I know increased congregations will be the result.-Yours, \&c., Alexander M. Gifford.

Hunstanton.

July 7 , I92I.

\section{GRAMOPHONE RECORDS}

SiR,-Some months ago you kindly published a letter of mine, in which I suggested that the makers of gramophone records might turn their attention to recording the music of our Elizabethan masters in music.

I read in the July number of the Musical Times the programme of the music as performed at the Congress on June I7. What a delight it would be to those who, like myself, are lovers of this class of music, if only the madrigals sung by the English Singers could be recorded. There are many of us living in remote places and far away from musical centres, who would gladly and quickly buy such records.

Some of the music from 'The Beggar's Opera' is recorded, and very tuneful and delightful it is, even if the words to the songs are not the original words as set to the tunes. These records sell, and perhaps more for the music than for the words. Much more would the old madrigals command a sale, with their exquisite words.

Please, Mr. Editor, use your influence and try and get such records for us to buy. - Yours, \&c.,

Seascale, Cumberland.

R. T. RICHMOND

(Country Dactor). July 5, I92 I.

\section{THE ORGANS AT FARM STREET CHURCH}

SIR,-In his article, 'Some Notable English Organs,' contributed to your July issue, Mr. Jay made some interesting references to the large Annessens organ in Farm Street Church. The general impression is that one of the present organs contains a considerable amount of Annessens' work. May I point out that this is hardly correct? The large west-end organ was originally an Annessens, but unfortunately suffered from an inherent and far too common defect in Continental-built organs, i.e., the use of unsuitable material in construction. The result was that the action was by no means durable, and became a constant charge for repairs and renewals, although Messrs. Bishop \& Son were fairly successful in maintaining it in a playable condition. Examination showed that the complicated mechanism was completely worn out, and a great many of the pipes, which were taken to be of good spotted metal, proved to be of much baser material. A new instrument was obviously the only solution, and the Annessens organ was scrapped except for the case, the bodies of a few of the large wooden pipes, and some reeds. It was first used, in a very incomplete condition, for the Requiem of the Archduke Ferdinand of Austria, whose assassination at Seravejo was the signal for the world-war.

The organ was voiced in the church to suit the somewhat difficult acoustics of the building, and in construction and tonal features it embodied preferences of the then Father Superior and of the organist, Mr. H. W. Brewer (recently deceased), who filled the post for upwards of thirty years and retired in 1916. In that year the organ passed to Messrs. Willis, Son \& Lewis, who re-voiced a portion of it and replaced a number of pipes; also they substituted a Willis Tuha.

They have since renovated the small organ in the Chapel of St. Ignatus.

The electric blowing machinery of these organs is an interesting example of what is attainable with the now little used system of crank-driven feeders. That of the large organ is installed in a room on a level with the church door close by the entrance. The drive is through a worm reducing gear and three-throw crank-shaft actuating six vertical feeders. The machinery and motor for the small organ are below the chapel floor (about 4 -ft.), access being obtained by removing the floorboards. Both are quite inaudible whilst working. I have never come across any so quiet.-Yours, \&c.,

II4, Mount Street, W. I.

VIVIAN STUART

July I3, I92 I. 